\title{
DYNAMIC OF LAND DEGRADATION NEUTRALITY BASELINE INDCATORS IN THE REPUBLIC OF MACEDONIA ${ }^{\#}$
}

\author{
Dusko Mukaetov ${ }^{1}$, Ivan Blinkov ${ }^{2,3}$, Hristina Poposka ${ }^{1}$ \\ ${ }^{1}$ Institute of Agriculture, Ss. Cyril and Methodius University, Skopje, Republic of Macedonia \\ ${ }^{2}$ Faculty of Forestry, Ss. Cyril and Methodius University, Skopje, Republic of Macedonia \\ ${ }^{3}$ Research Center for Environment and Materials, Macedonian Academy of Science and Art, \\ Skopje, Republic of Macedonia \\ e-mail: d.mukaetov@t-home.mk, blinkov@sf.ukim.edu.mk, hristinapoposka@hotmail.com
}

\begin{abstract}
Land degradation neutrality (LDN) is defined as a "state whereby the amount and quality of land resources necessary to support ecosystem functions and services and enhance food security remain stable or increase within specified temporal and spatial scales and ecosystems". The baseline is expressed as the initial $\left(\mathrm{t}_{0}\right)$ estimated value of each of the three indicators, used as proxies of land-based natural capital and the ecosystem services that flow from that land base: land cover/land use change, land productivity status and trends, soil organic carbon status and trends. The baseline of LDN was calculated with estimation of the average values across the 10 years baseline period of the following indicators: Land Cover/Land Cover change (LC/LCC), Land Productivity Dynamics (LPD) and Soil Organic Carbon (SOC). Three tier approaches for computation of the selected indicators were used: Tier 1: Global/regional Earth observation, geospatial information and modelling; Tier 2: National statistics (only for LC/LCC) and Tier 3: Field survey. Most significant changes in LC for the period 2000/2012 are in the categories of Forest land and Shrubs/grasslands. According the global data sets used for analysis of LPD, the total affected area with depletion of Land productivity for the period $2000 / 2010$ is identified on a only $2.35 \%$ of the country territory. The available global data sets gives a model SOC levels for the period 2000/2010. According these data, the total loss of SOC in our country is estimated on $3951 t$.
\end{abstract}

Key words: land degradation neutrality; land cover/use changes; land productivity; SOM

\section{INTRODUCTION}

Demands on global land resources are increasing as the world's population increases in number and affluence, yet the health and productivity of land is deteriorating [1]. Land degradation is a consistent loss of ecosystem functionality due to human and natural processes [2].

Land degradation is an interactive process involving multiple causal factors, among which climate variability, soil quality and land management play a significant role [3]. Land degradation is a global concern for sustainable development, conservation of biodiversity and mitigating and adapting to climate change. It refers to reduction or loss of the biological or economic productivity and complexity of land, reducing carbon storage in soil and vegetation, driving the loss of biodiversity and accelerating climate change [4].
Land degradation affects livelihoods, biodiversity and ecosystem services through reduction or loss of the biological or economic productivity and complexity of rain fed cropland, irrigated cropland, or range, pasture, forest and woodlands resulting from land uses or from a process or combination of processes arising from human activities [5].

Increased competition for land resources will increase social and political instability, exacerbating food insecurity, poverty, conflict and migration [6].

The concept of Land Degradation Neutrality (LDN) has been adopted as part of the 2030 Agenda for Sustainable Development and is enshrined in Target 15.3: "by 2030, combat desertification, and restore degraded land and soil, including land affected by desertification, drought and floods, and strive to achieve a land-degradation neutral world".

While Sustainable Development Goals SDG15, calls for the protection of terrestrial ecosys- 
tems and the fight against land degradation in general terms, target 15.3 explicitly formulates the vision of a "land degradation neutral world" [7].

LDN is defined as a "state whereby the amount and quality of land resources necessary to support ecosystem functions and services and enhance food security remain stable or increase within specified temporal and spatial scales and ecosystems" [8].

The LDN conceptual framework focuses on the supporting processes required to deliver LDN, including biophysical and socio-economic aspects, and their interactions. Neutrality implies no net loss of the land-based natural capital relative to a reference state, or baseline [9].

LDN target setting is a complex process that includes numerous political and technical aspects. The concept of Land Degradation Neutrality (no net loss) is a maintenance or enhancement of the status of land based natural capital degradation in relation to a referent state (base line), hence the "base line" becomes a "target to be achieved" in order to maintain the neutrality of degradation processes. The LDN related to the "base line" maintenance is considered as a minimum target.

The accepted base line indicators are a) Land cover changes, b) Land productivity dynamics and c) Carbon stocks (bellow and above ground). These indicators are chosen to be used since they provide a good evaluation of the land based eco system services, these soil variables gives a good hint of soil quality and together can be used to monitor the quantity and quality of land-based natural capital.

In addition, the indicators address change in the system in different yet highly relevant ways: a) land cover provides a first indication of a reduction or increase in vegetation, habitat fragmentation and land conversion, b) land productivity captures relatively fast changes while c) SOC reflects slower changes that suggest trajectory and proximity to thresholds. Land degradation trends analysis is an important step in the process LDN, since it should not be an expression of the current status of LD, but a chronological assessment of land degradation processes and drivers, which is crucial for understanding of the current conditions of land degradation, revealing anomalies and identifying degraded areas. Such evidence based assessment provides a sound base for LDN target setting and identifying needs and opportunities of interventions [10].

Primarily, comparable and standardised national official data sources were used for calculation of "base line", identification of hot-spots and trends of land degradation

Main aim of this work was defining the LDN baseline indicators and their dynamic in the last 10 years in the Republic of Macedonia.

\section{EXPERIMENTAL SECTION}

The baseline is expressed as the initial $\left(\mathrm{t}_{0}\right)$ estimated value of each of the three indicators used as proxies of land-based natural capital and the ecosystem services that flow from that land base.

- $\quad$ Land Cover/Land Cover change,

- Land Productivity status and trends,

- Soil Organic Carbon status and trends

Land cover refers to the observed physical cover of the Earth's surface, which describes the distribution of vegetation types, water bodies and human-made infrastructure. It also reflects the use of land resources (i.e., soil, water and biodiversity) for agriculture, forestry, human settlements and other purposes [11].

Land cover provides a first indication of changing vegetation cover, to some extent as proxy of the underlying use, and of land conversion and resulting habitat fragmentation. Land Cover can be considered as indicator for the sensitivity of land to degradaton related to socio-ecological dynamics of land management, especially: land abandonment and unsustainable use of rural and peri-urban areas [12].

Land productivity refers to the total aboveground net primary productivity (NPP) defined as the energy fixed by plants minus their respiration which translates into the rate of biomass accumulation that delivers a suite of ecosystem services. Land productivity captures relatively fast changes in land capability for bio production.

Soil organic carbon (SOC): carbon stock is the quantity of carbon in a pool (i.e., a system which has the capacity to accumulate or release carbon). Carbon pools are biomass (above-ground biomass and below-ground biomass), dead organic matter (dead wood and litter), and soil (soil organic matter). It is a summarizing parameter including all of the carbon forms of dissolved (DOC: Dissolved Organic Carbon) and total organic compounds (TOC: Total Organic Carbon) in soils [10].

The baseline LDN indicators were calculated with estimating of each of the following indicators, the average value across the 10 years baseline period.

There are 3 Tier approaches for computation of the selected indicators. The Tier approach, generally provides advice on estimation methods used at three levels of detail, from Tier 1 (the default method) to Tier 3 (the most detailed method). In the context of the LDN TSP, the following approach were used:

- Tier 1: Global/regional Earth observation, geospatial information and modelling;

- Tier 2: National statistics based on data acquired for administrative or natural reference units (e.g. watersheds) and national earth observation; 
- Tier 3: Field surveys, assessments and ground measurements.

Such approach, allows to use methods consistent with national capacities, resources and data availability and facilitates comparability at global level.
For our work in the absence of national data generated from field surveys and ground measurements, the global graphical data sets were provided for the 3 indicators used in the process of the "base line" assessment as presented in the Table 1. Global data sets are generated from various referent sources.

Table 1. Default Tier 1 data provided by LDN TSP - Global Data Set

\begin{tabular}{lc}
\hline Indicator (metric) & Default Tier 1 data source \\
\hline Land cover & $\begin{array}{l}\text { ESA Climate Change Initiative Land Cover dataset : spatial resolu- } \\
\text { tion 300m; 3 epochs 2000, 2005 and 2010 (2015 available shortly) }\end{array}$ \\
\hline $\begin{array}{l}\text { Land productivity } \\
\text { (net primary productivity) }\end{array}$ & $\begin{array}{l}\text { JRC Land Productivity Dynamics dataset:15-year time series (1999 } \\
\text { to 2013) of SPOT Vegetation NDVI; spatial resolution 1 km. }\end{array}$ \\
\hline $\begin{array}{l}\text { Carbon stocks above and below ground } \\
\text { (SOC) }\end{array}$ & ISRIC SoilGrids250m (2016, in prep.) \\
\hline
\end{tabular}

Table 2. Description of LC categories

\begin{tabular}{|c|c|c|c|}
\hline Value & Categories & Short description & ESA CCI-LC classes (codes) \\
\hline 1 & Forests & $\begin{array}{l}\text { Geographical areas dominated by natural } \\
\text { tree plants with a cover of } 15 \% \text { or more. } \\
\text { This class also includes: } \\
\text { - mosaic tree and shrub (> 50\%) / herba- } \\
\text { ceous cover } \\
\text { - seasonally or permanently tree flooded } \\
\text { with fresh water }\end{array}$ & $\begin{array}{l}\text { Tree broadleaved evergreen, } \\
\text { Tree broadleaved deciduous, } \\
\text { Tree needle leaved evergreen, } \\
\text { Tree needle leaved deciduous, } \\
\text { Tree mixed leaf type, } \\
\text { Mosaic tree, shrub / herbaceous cover, } \\
\text { Tree flooded, fresh water } \\
(50,60,61,62,70,71,72,80,81,82 \text {, } \\
90,100,160)\end{array}$ \\
\hline 2 & $\begin{array}{l}\text { Shrubs, grasslands } \\
\text { and sparsely } \\
\text { vegetated areas }\end{array}$ & $\begin{array}{l}\text { Geographical areas dominated by: } \\
\text { - natural shrubs; or } \\
\text { - natural herbaceous plants; or } \\
\text { - sparse natural vegetation with a cover of } \\
15 \% \text { or less; } \\
\text { This class also include: } \\
\text { - mosaic natural vegetation }(>50 \%) / \text { crops } \\
\text { - mosaic herbaceous cover }(>50 \%) / \text { tree } \\
\text { and shrub }\end{array}$ & $\begin{array}{l}\text { Mosaic natural vegetation / cropland, } \\
\text { Mosaic herbaceous cover / tree, shrub, } \\
\text { Scrublands, } \\
\text { Grassland, } \\
\text { Lichens and mosses, } \\
\text { Sparse vegetation } \\
(40,110,120,121,122,130,140,150 \text {, } \\
152,153)\end{array}$ \\
\hline 3 & Cropland & $\begin{array}{l}\text { Geographical areas dominated by: } \\
\text { - herbaceous crops; or } \\
\text { - woody crops; or } \\
\text { - mixed herbaceous and woody crops; } \\
\text { This class also include: } \\
\text { - mosaic crops }(50 \%) \text { / natural vegetation }\end{array}$ & $\begin{array}{l}\text { Cropland rainfed, } \\
\text { Herbaceous cover } \\
\text { Tree or shrub cover } \\
\text { Cropland, irrigated or post-flooding, } \\
\text { Mosaic cropland / natural vegetation } \\
(10,11,12,20,30)\end{array}$ \\
\hline 4 & $\begin{array}{l}\text { Wetlands and } \\
\text { water bodies }\end{array}$ & $\begin{array}{l}\text { Geographical areas dominated by: } \\
\text { - shrub or herbaceous vegetation, aquatic } \\
\text { or regularly flooded; or } \\
\text { - mangroves or } \\
\text { - water bodies (natural / artificial, } \\
\text { standing / flowing, inland / sea) }\end{array}$ & $\begin{array}{l}\text { Tree cover, flooded, saline water, } \\
\text { Shrub or herbaceous cover, flooded, } \\
\text { fresh/saline/brackish water } \\
\text { Water bodies } \\
(170,180,210)\end{array}$ \\
\hline 5 & Artificial areas & $\begin{array}{l}\text { Geographical areas dominated by artifi- } \\
\text { cial surfaces, including urban and associ- } \\
\text { ated areas (e.g. urban parks), transport } \\
\text { infrastructures, industrial areas, burnt } \\
\text { areas, waste deposits, extraction sites. }\end{array}$ & $\begin{array}{l}\text { Urban areas } \\
(190)\end{array}$ \\
\hline 6 & $\begin{array}{l}\text { Bare land and } \\
\text { other areas }\end{array}$ & $\begin{array}{l}\text { Geographical areas dominated by: } \\
\text { - bare areas or } \\
\text { - snow and glaciers }\end{array}$ & $\begin{array}{l}\text { Bare areas, } \\
\text { Permanent snow and ice } \\
(200,201,202,220)\end{array}$ \\
\hline
\end{tabular}


Global data sets used for all three indicators were in format different from the national standards; hence, the initial step in this research was to convert the digital data sets which enables its overlapping with other national data sets for the future in depth analysis.

As for the LC/LCC indicator, LC classes within ESA-CCI significantly differs from these used in CORINE LC dataset. In order to make both data sets comparable, the following approach of harmonization and reclassification was uses (Table 2).

The dynamics of LC/LCC has been analyzed over 10 years period with comparison of ESA-CCI data sets for year 2000 and year 2010, while for CORINE LC datasets were used for the period 2000-2012.

Land productivity refers to the biological productive capacity of the land, as source of all the food, fiber, and fuel that sustains humans [5].

The JRC's Land Productivity Dynamics (LPD) dataset is used as default source for land productivity data. The LPD dataset used, was derived from a 15year time series (1999 to 2013) of SPOT Vegetation global NDVI observations composited in 10-day intervals at a spatial resolution of $1 \mathrm{~km}$.

Global data set used during setting of the "base line" and estimation of SOM dynamic has been derived by the International Soil Reference and Information Centre (ISRIC).

All digital analyses were launched in a GIS environment using an appropriate software: ArcGIS 10.1 and QGis 3.1.

Finally, all results about land degradation hotspots, were checked and validated through onfield work, by recognition of the terrain and collecting relevant historical information from local people for the previously defined hotspots.

\section{RESULTS AND DISCUSSION}

\section{Land Cover/Land Cover Changes}

Global data recommended for validation of LC/LCC dynamics are originated from the European Space Agency-Climate Change Initiative for the periods 2000/2010 (Figure 1). In addition, it was recommended, if possible, to use national referent digital data sets. For this purpose, in our work the recommended global data set of LC (ESA-CCI) was compared with the existing data set of CORINE LC data base for the country.
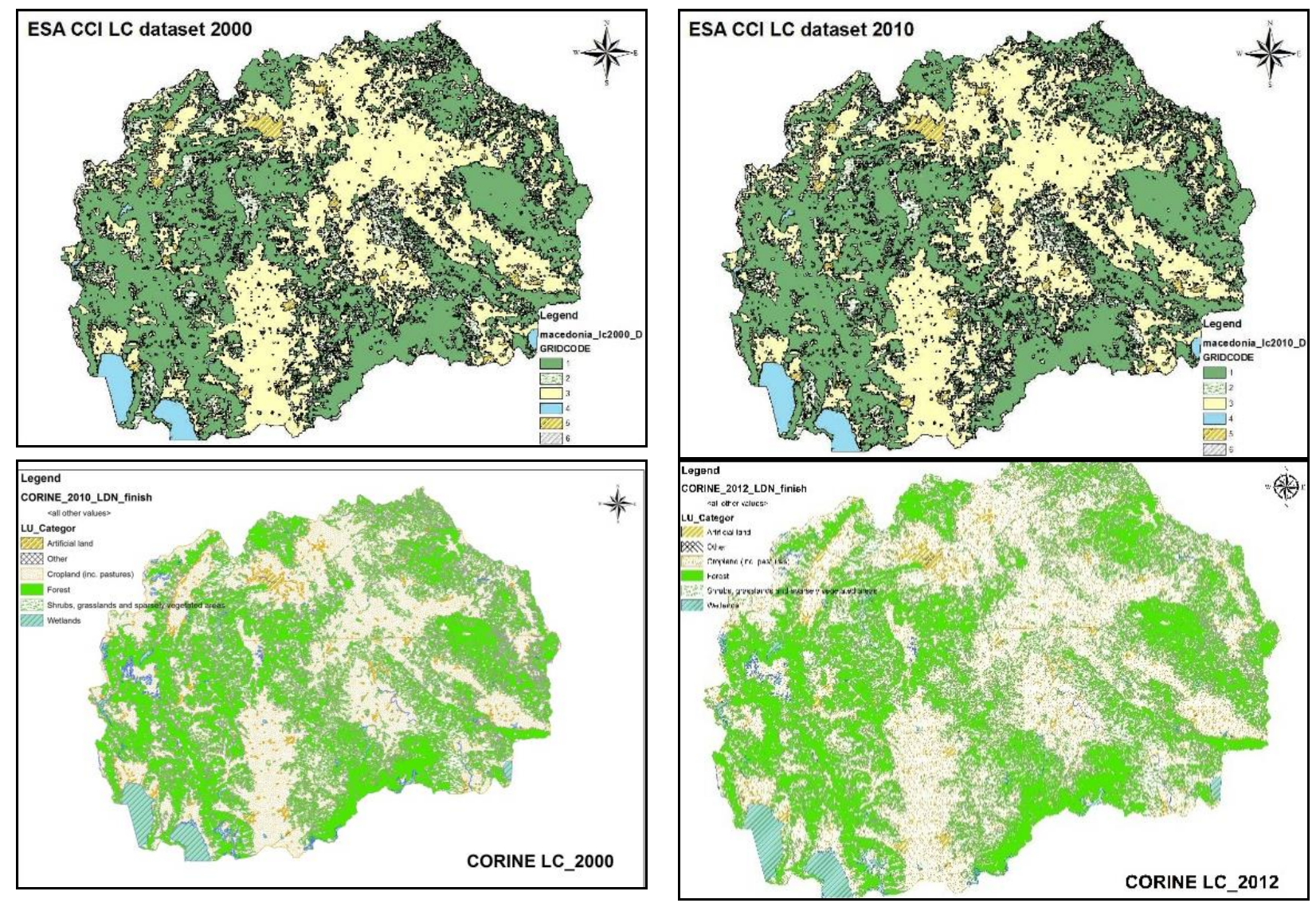

Figure 1. Land Cover by ESA CCI, 2000 and 2010 
This data base was previously used in the country for many other analysis of LC and is concerned as the only existing referent data base of LC on a country level. The periods used for this comparison were 2000-2012. The classes of the LC in CORINE LCU on level 3, were grouped into 6 categories in a line with the IPCC Guidelines. Similar reclassification has been already made for the ESACCI data set as well.
For better comparison of the LC/LCC, vector files containing info for the spatial distribution of LC under each of the 6 categories, for each period for the both digital datasets were developed, as presented in (Figure 2). This procedure, enables calculation and comparison of the surface area under each of LC categories for both periods.
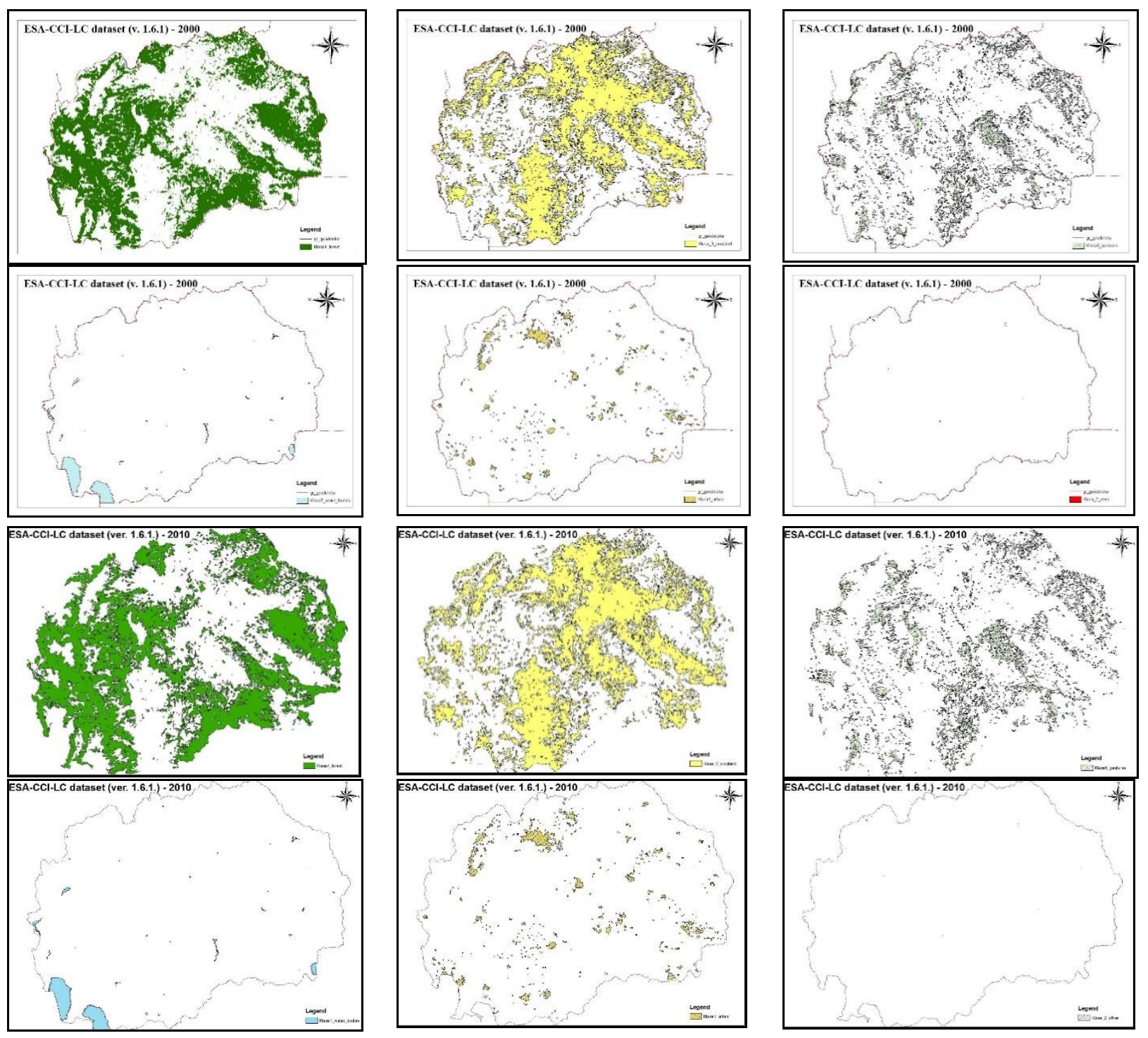

Figure 2. Separate ESA - LC categories of land use for the year 2010 and 2010

In the Figure 3 a land use change for both data sets are presented graphically, while the cumulative areas of land use change for each category are presented in Table 3.

Out of the presented data, a differences between the two datasets: ESA_CCI and CORINE LC in terms of LC change for the period 2000/2010 are significant. Most significant differences are notable among the first two categories forest and shrubs, grassland and sparsely vegetated areas. The ESA-CCI data base recognizes a total loss of 6, 5 sq. km, out of which 3, 9 sq. $\mathrm{km}$ are converted to shrubs, grassland and sparsely vegetated areas and 2, 9 to cropland. According this data base, there is no other land cover changes with the other 3 categories: wetland and water bodies, artificial areas and bare land and other areas. 

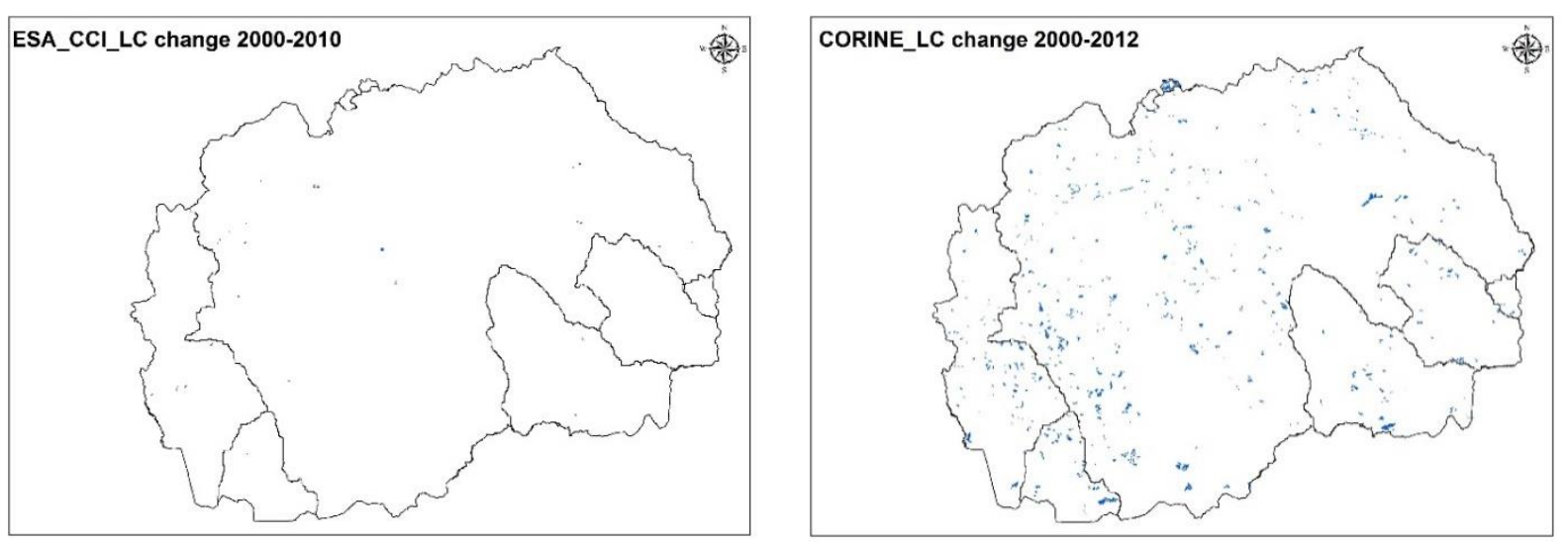

Figure 3. Land Cover change - differences ESIA-CCI and CORINE LC

Out of the data presented in Table 3 and 4, it can be noticed that according CORINE LC data base, the most significant changes in LC for the period 2000/2012 are in the categories of Forest and
SG\&Sva. Most probably the majority of reduced areas under forests are result of conversion to SH\&Sva, in the process of interpretation of the satellite images for the period.

Table 3. Area under different categories of LC of CORINE Land Cover Data base

\begin{tabular}{lrrrrrr}
\hline CLC categories & \multicolumn{3}{c}{ ESA-CCI, in $\mathrm{km}^{2}$} & \multicolumn{2}{c}{ CORINE Land cover in $\mathrm{km}^{2}$} \\
\cline { 2 - 7 } & 2000 & 2010 & $\begin{array}{l}\text { Net area } \\
\text { change }\end{array}$ & 2000 & 2010 & $\begin{array}{l}\text { Net area } \\
\text { change }\end{array}$ \\
\hline Forest (F) & 11.159 .00 & 11.152 .00 & -6.50 & 8.608 .50 & 8.242 .66 & -365.83 \\
\hline $\begin{array}{l}\text { Shrubs, grassland and sparsely veg- } \\
\text { tated areas (SG\&Sva) }\end{array}$ & 2.631 .00 & 2.635 .00 & 3.90 & 4.388 .61 & 4.722 .81 & 334.20 \\
\hline Cropland (C) & 10.345 .00 & 10.347 .00 & 2.6 & $11.256,61$ & 11.228 .94 & -27.67 \\
\hline Wetland and water bodies (W\&Wb) & 497.00 & 497.00 & 0.00 & 723,11 & 698.30 & -24.82 \\
\hline Artificial areas (Aa) & 713.00 & 713.00 & 0.00 & 387,18 & 428.44 & 41.25 \\
\hline Bare land and other areas (Bl\&Oa) & 4.00 & 4.00 & 0.00 & 74,26 & 113.54 & 39.28 \\
\hline Total & 25.349 .00 & 25.349 .00 & & 25.438 .27 & 25.434 .69 & \\
\hline
\end{tabular}

The reasons of this changes are result of forest fires in 2007 when almost 40000 ha were burned. After fire, the land is bare and in the next period the self-restoration usually starts, firstly as a ground flora: grass and bushes and later in most cases forest species. For decoding and calculation of LC changes in 2010 aerial images from the period 2008/9 were used when significant land areas were affected with forest fires due to what in most cases forest areas were classified in the category of SG\&Sva. There is also a notable increasing of the categories of bare-land $\left(39,28 \mathrm{~km}^{2}\right)$ and artificial land $\left(41,25 \mathrm{~km}^{2}\right)$ which is most probably result of urban expansion and conversion of fertile cropland and pastures. Of particular interest is the decreasing of the area classified as wetlands\& water bodies. There are several reasons for this: errors which might appeared during the photointerpretation of satellite images, drought that cause decrease of water level and surface area of the Prespa Lake and variations of water level and surface area of the reservoirs due to the intensive usage of water for irrigation.

Changes in land cover may be characterized as positive or negative when contextualized with national or local information. Some critical transitions are generally considered as negative, for instance those:

- from natural or semi-natural land cover classes to cropland or settlements;

- from forest land to other land cover classes (i.e. deforestation), as well as those

- from natural or semi-natural land cover classes and cropland to settlements (i.e. urbanization). 
Table 4. LC changes and its effects on land productivity (ha)

\begin{tabular}{|c|c|c|c|c|c|c|c|c|}
\hline \multirow{2}{*}{$\begin{array}{c}\text { Land cover } \\
\text { type }\end{array}$} & \multirow{2}{*}{$\begin{array}{l}\text { Area of LC } \\
\text { changes }\end{array}$} & \multicolumn{6}{|c|}{ Converted to } & \multirow{2}{*}{$\begin{array}{l}\text { LUC Hot } \\
\text { Spots }\end{array}$} \\
\hline & & Forest & Shrubs & Cropland* & Wetland & Urban & Other & \\
\hline Forest land & 13.404 .31 & 68.17 & $12.898 .81^{a}$ & & $3.12^{a}$ & $11.77^{a}$ & $422.44^{a}$ & 13.336 .14 \\
\hline Shrubs & 7.910 .81 & $7.192 .24^{b}$ & - & $281.27^{a}$ & $164.87^{a}$ & - & $272.44^{a}$ & 718.58 \\
\hline Cropland* & 4.328 .37 & $266.09^{b}$ & $373.49^{b}$ & 2780.13 & 21.35 & $27.24^{a}$ & $860.07^{a}$ & - \\
\hline cropland & 3.307 .63 & $191.73^{b}$ & $208.24^{b}$ & $2368.7^{b}$ & - & 11.49 & 527.46 & 538.96 \\
\hline pastures & 1.020 .73 & $74.36^{b}$ & $165.24^{a}$ & $411.42^{a}$ & $21.35^{a}$ & $15.75^{a}$ & $332.61^{a}$ & 946.37 \\
\hline Wetland & 347.95 & $91.39^{b}$ & - & - & 247.23 & $9.33^{a}$ & - & 9.33 \\
\hline Urban & 5.67 & - & - & - & $5.67^{b}$ & - & - & - \\
\hline Other & 638.37 & - & $112.13^{b}$ & $391.93^{b}$ & $48.46^{b}$ & $57.72^{a}$ & 28.13 & 57.72 \\
\hline $\begin{array}{c}\text { TOTAL } \\
\text { CHANGE }\end{array}$ & 26.635 .49 & & 13.064 .05 & 692.69 & 189.34 & 106.07 & 1554.94 & $15.607 .1^{a}$ \\
\hline
\end{tabular}

$a$ - decline of land productivity (negative changes); $b$-improvement of land productivity (positive change)

*Sum of cropland and pastures

\section{Land Productivity Dynamics}

Land productivity is an expression of the bioproductivityof all land components and their interaction, especially for regional assessments, not just those components related to human activities and direct use. Therefore, Land productivity is not to be confused with agricultural productivity [13].

Land productivity points to long-term changes in the health and productive capacity of the land and reflects the net effects of changes in ecosystem functioning on plant and biomass growth. Land productivity is also important for assessing changes in the carbon stocks of natural and managed systems, and thus their contribution to climate change mitigation efforts. LPD was performed on the base of the NDVI analysis for estimation of Net Plan Productivity. The Normalized Difference Vegetation Index (NDVI) so far is the most commonly used vegetation index. Simmilar analysis for estimation of total anyal biomass (TWB) and NPP for big areas or global level with usage of MODIS data set can be find in the work of Conijn at al. [14].

The normalized difference vegetation index (NDVI) is a simple numerical indicator that can be used to analyze remote sensing data and assess whether the target area contains live green vegetation [15]. NDVI is one of the simplest and most frequently used indices in plant studies [16].

The LPD dataset provides 5 qualitative classes of land productivity trends over the above mentioned time period. These qualitative classes do not directly correspond to a quantitative measure (e.g. t/ha of NPP or GPP) of lost or gained biomass productivity. The 5 classes are rather a qualitative combined measure of the intensity and persistence of negative or positive trends and changes of the photo-synthetically active vegetation cover over the observed period.

The JRC dataset's $1 \mathrm{~km}$ resolution is unlikely to be of appropriate scale to reflect human activities at a sub-national scale [17], especially in small scale landscape mosaics. Still, in a case of missing of national data sets, UNCCD suggests using the abovementioned dataset and classification to determine the degree of land degradation.

As mentioned before, LPD data set provides 5 classes of land productivity (Table 5), among which the first 3 classes are considered to be an indication of potential land productivity decline, as an indicator of land degradation.

Table 5. Classes of Land Productivity Dynamics (LPD)

\begin{tabular}{clr}
\hline Value & \multicolumn{1}{c}{ Description } \\
\hline 1 & Declining productivity & \\
\cline { 1 - 2 } 2 & Early signs of decline & unacceptable \\
\hline 3 & Stable, but stressed & \\
\hline 4 & Stable, not stressed & acceptable \\
\hline 5 & Increasing productivity & \\
\hline
\end{tabular}

The Global data set for LPD was transformed into national projection for its further use with other re-projected data sets in the process of "base line" assessment (Figure 4). The LDN raster data set was converted into shape file. All classes were identified, integrated separated into separate files.

This was necessary, to identify the total area and spatial distribution of the first 3 classes which indicate decline or stress in terms of land productivity. 

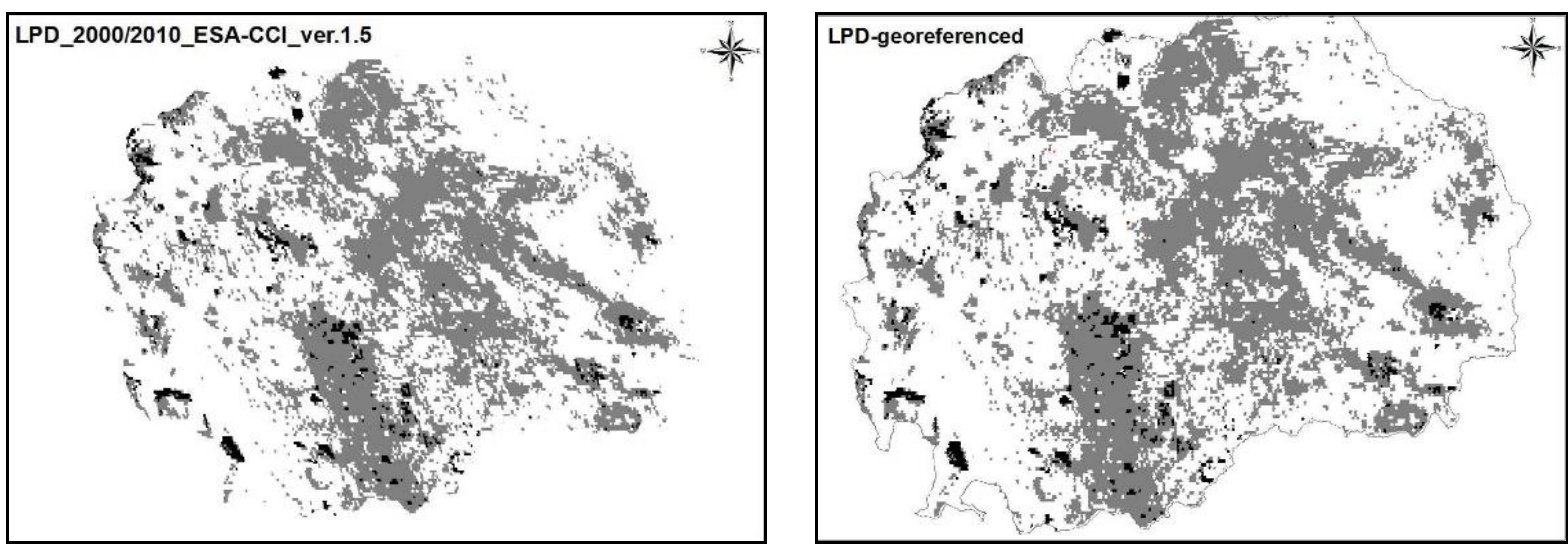

Figure 4. LPD data transformed in Macedonian geodetic system - an example dataset 2000

In Figure 5, are presented all 5 classes that present Land productivity dynamic (map on the left hand side) while on the other map are presented areas with unacceptable LPD classes' (1-3 class).
According to the calculations, the total area of LPD defined as unacceptable or only $2.35 \%$ of the territory of the country and it seems as to be very small area, but in reality it is $\mathbf{5 8} 500$ ha with negative land productivity dynamic.
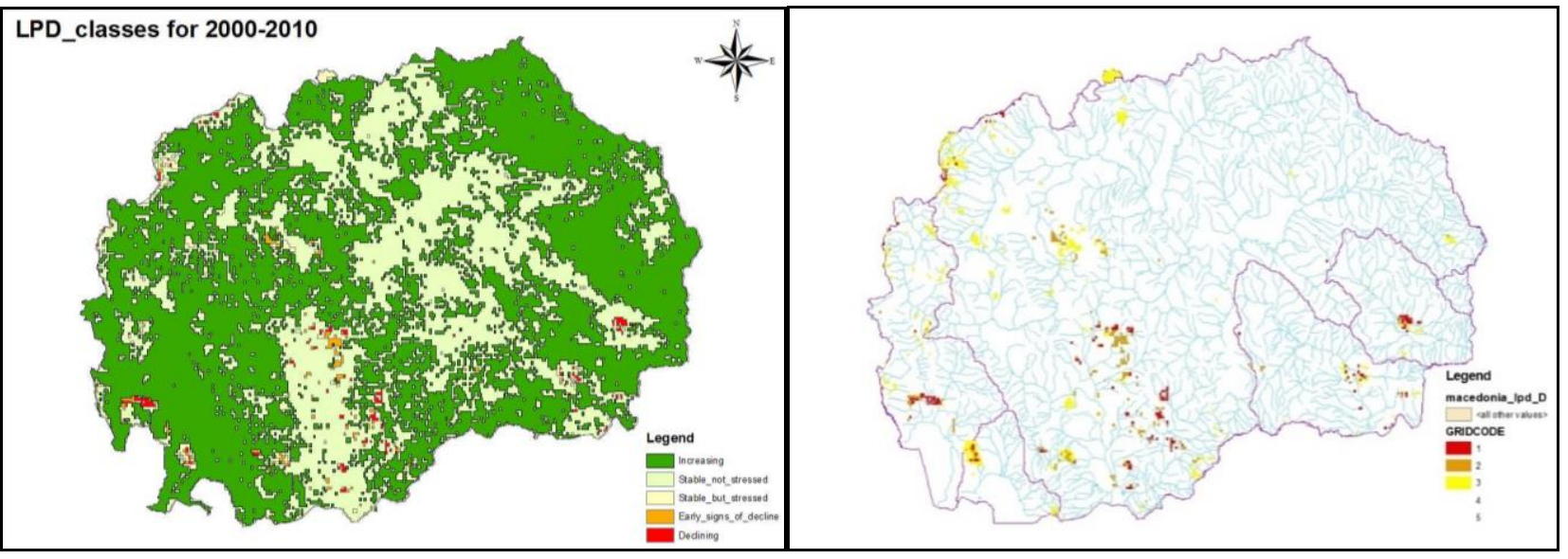

Figure 5. Land Productivity dynamics

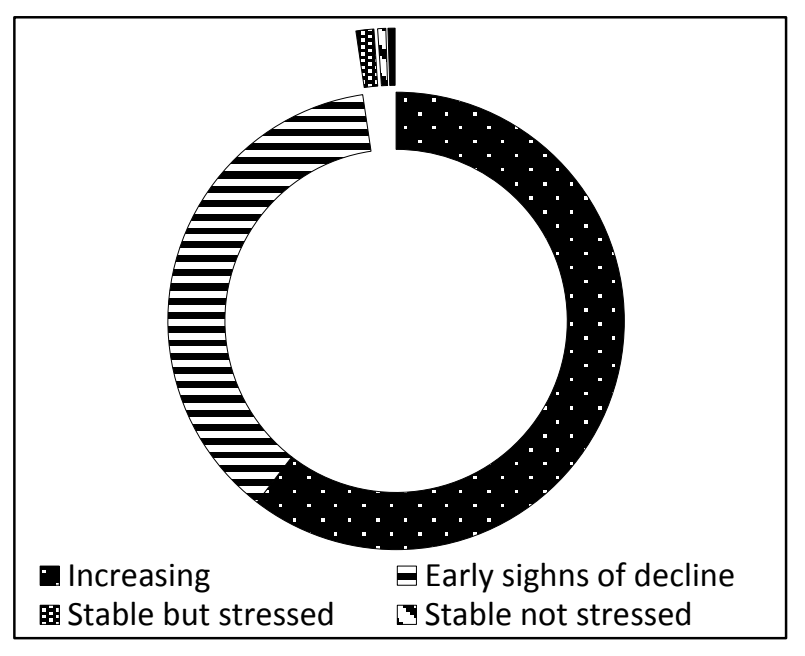

Figure 6. Distribution of the territory of the Republic of Macedonia per LPD classes $-\left[\mathrm{km}^{2}\right]$
Dengiz [18] reports data for land productivity dynamics (LPD) of a degraded catchment located in sub-humid terrestrial ecosystem estimated via a land degradation assessment using three indicators: LC, land productivity, and SOC density. In more than $23 \%$ of the catchments' area of approx. 3896 ha, land productivity is observed to decline while about $24 \%$ shows early signs of decline level (Figure 6).

\section{Soil Organic Carbon dynamic}

Soils contain the largest dynamic reservoir of carbon on Earth. This makes soils a critical component of the global carbon cycle [19]. The factors controlling the rates andprocesses for SOC accumulation and lossinclude many factors, like: climate, topographic position, parent material, 
potential biota, time, and human activity; these are also thefactors that govern soil formation in general, hence the monitorign of SOC dynamuc is a very complex task.Yang Li-xia and Pan Jian-jun [20] noted that modelling of SOC is an one of the possible approaches in estimation of SOC dynamics, suggesting that future soil organic matter models should be developed toward based-process models, and not always empirical ones.

With a reference to the third indicator analysed in the process of the "base line" assessment, it should be noted that, two types of information are required:

1. the baseline SOC stocks (e.g. ton/ha) for the country in the year of interest (here 2000), and

2. corellation of changing of land use/cover conditions to changes in SOC stocks (aboveground and belowground-soil organic carbon SOC).

For the purposes of this study, modeling of the SOC content based on over 150,000 soil profiles collected over several decades by ISRIC, the depth of the soil layer to the parent substrate, the content of the skeleton, the apparent density, and other covariables which are determined by means of remote sensing, and modeling of all realizations between these co-variables and the soil properties of the multi-index database for the soil has been modeled.In this way (although soil profiles have been monitored over the course of decades), the basic content of the SOC for 2000 has been set in a $250 \mathrm{~m}$ grid map.
To obtain an estimate of the change in SOC reserves in time period (2000-2010), suitable for setting LDN targets, a modified IPCC methodology is used that is used to produce National GHG inventories to predict the movements (changes) in SOC at the country level based on land use change / coverage [21].

The following dynamic trends (i.e. variables) were used to make a rough estimate of the change in SOC:

- the change in the soil cover/utilization associated with the ISRC assessment of the SOC content in 2000.

- The general bioclimatic zones (boreal, temperate, temperate continental, etc.) and the assumptions for change in the input of agricultural inputs with the change of soil cover/utilization, were considered as well.

On the base of these assumptions in change of land cover/land use change and inputs in different climatic zones, estimated quantities for each category of land cover was derived.

The general data set for the SOC was reprojected in a line with the national projection. The SOM raster file has been transformed from raster to shape file, and reclasified into 11 classes of SOM contents. Same procedure has been applied for both peridos 2000 and 2010 in order to idnetify the areas with decrease of SOM content in the surface layer $(0-30 \mathrm{~cm})$ in $\mathrm{t} / \mathrm{ha}$ (Figure 7$)$.

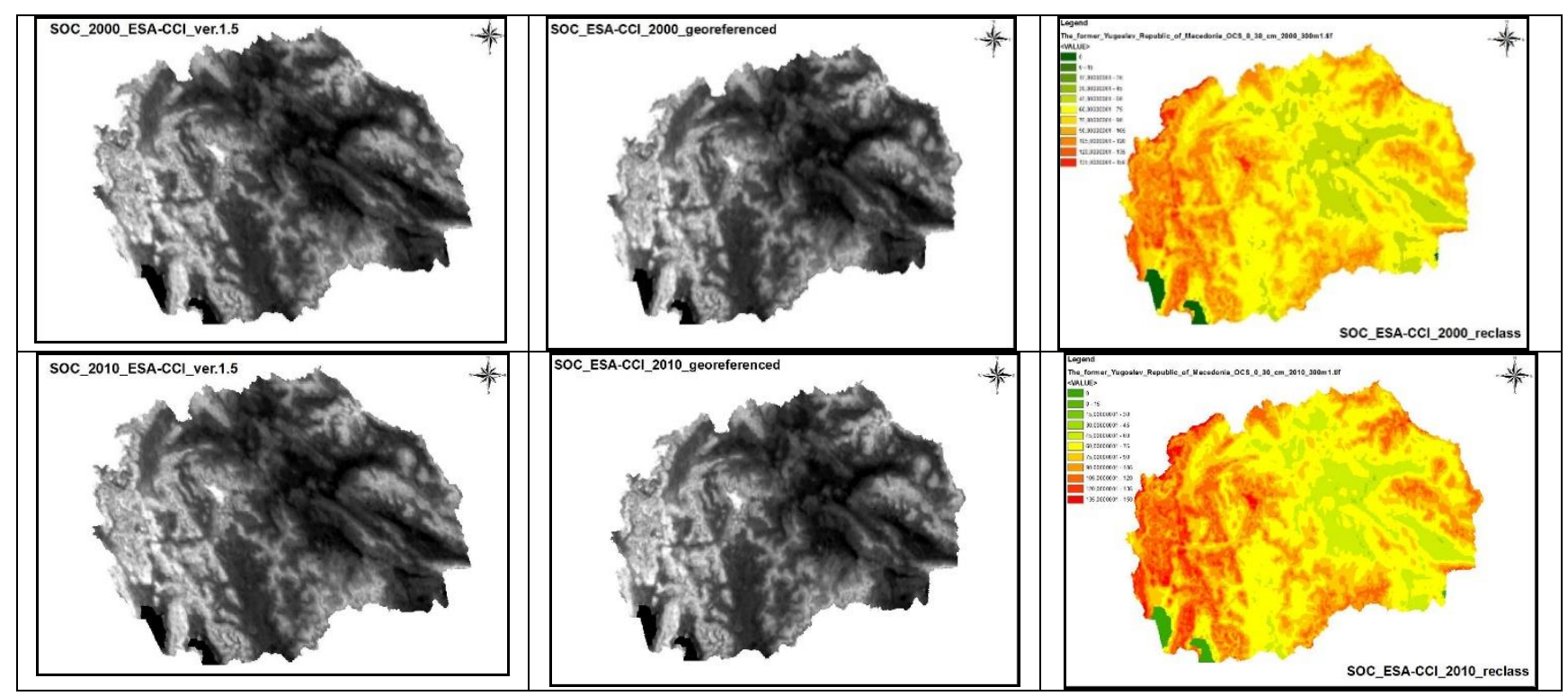

Figure 7. -SOM content classes spatial distribution for 2000 and 2010 


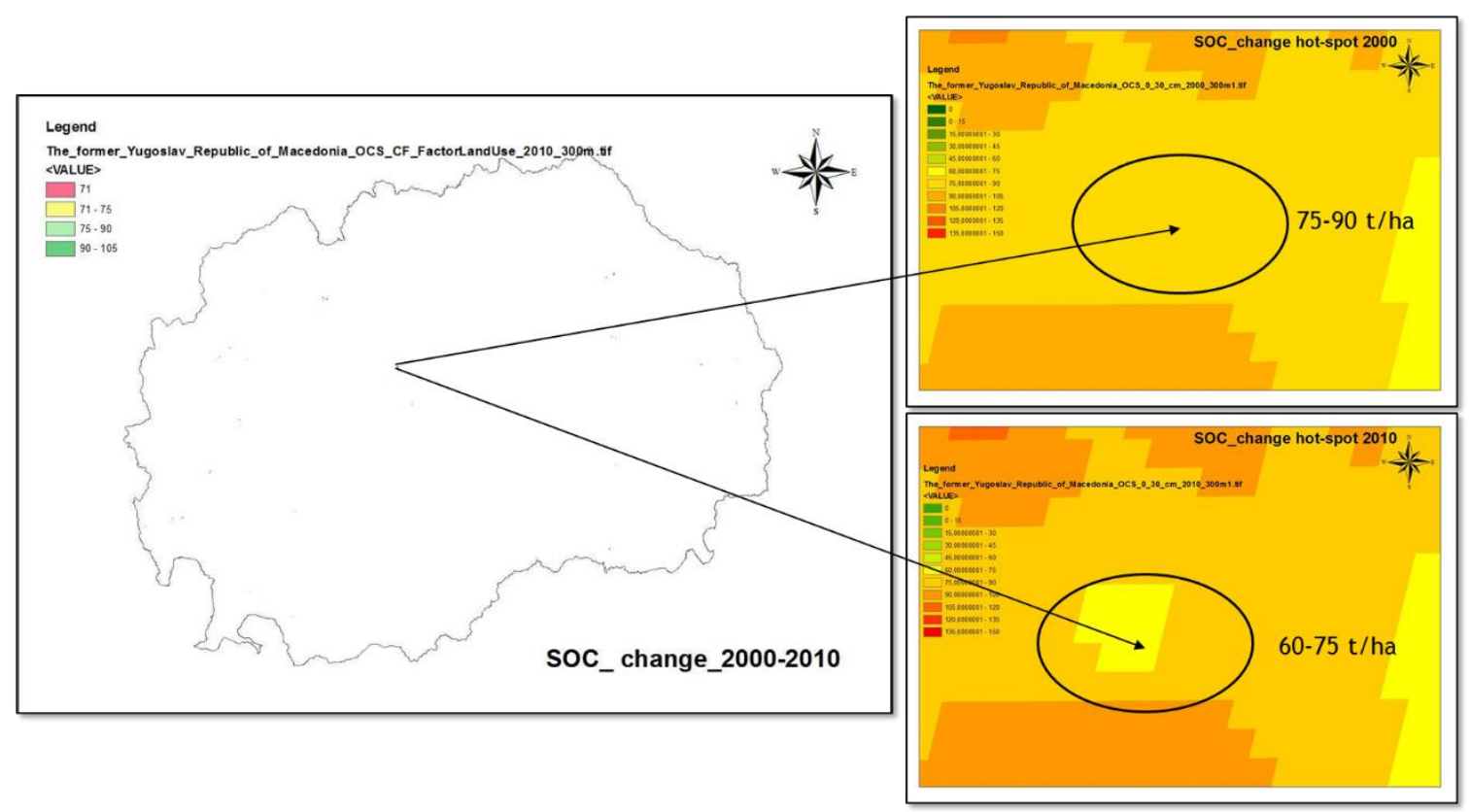

Figure 8. Area with SOM changes

The differences in soil organic matter are presented in Table 6 and Figure 8. SOC change is related and calculated on the base of land use change.
Out of the presented data it can be seen that conversion of forest to cropland $\left(2.6 \mathrm{~km}^{2}\right)$ for the period 2000/2010 yields a total SOC decreasing of $3951 \mathrm{t}$.

Table 6. SOC change for the period 2000/2010

\begin{tabular}{rcccccc}
\hline & Net area change & \multicolumn{3}{c}{ Soil organic carbon 0 - 30 cm (2000-2010) } \\
\cline { 2 - 7 } Conversion of LC classes & \multirow{2}{*}{$\mathrm{km}^{2}$} & \multicolumn{4}{c}{ total (t) } & \multicolumn{3}{c}{ loss (t) } \\
Forest to Cropland & 2.6 & 2000 & 2010 & 2000 & 2010 & $2000 / 10$ \\
\hline $\begin{array}{r}\text { Forest to Shrubs, grasslands and } \\
\text { sparsely vegetated areas }\end{array}$ & 3.9 & 86.6 & 71.4 & 22590 & 18639 & -3951 \\
\hline Total & -6.5 & - & - & 57114 & 53163 & 0 \\
\hline Total loss of SOC stock (country) & & & & & & -3951 \\
\hline
\end{tabular}

\section{CUMULATIVE LAND DEGRADATION TRENDS}

The three indicators used for setting the baseline (i.e. land cover, land productivity and carbon stocks above and below ground (metric: SOC)), complemented as needed by nationally relevant indicators, can also be used to assess trends. When setting the baseline, it is necessary to estimate for each indicator, the average value across the fiveyear baseline period. However a retrospective trend analysis requires an observation of the changes in the value of the indicators over a 10-15 year assessment period prior to the current condition (in our case 2000/2010).

As these indicators are complementary rather than additive and components of land condition, they should be analysed separately. However, land cover, being considered as an important indicator in itself, should also be used to stratify the other two indicators.

Degradation is generally considered to occur when:

- land productivity shows a significant negative trend; or

- SOC shows a significant negative trend; or

- negative land cover change occurs; or

- a negative change occurs in another nationally relevant indicator.

However, trends in the indicators need to be interpreted in the context of local conditions. Cumulative land degradation consists of area with negative trends in LPD (I - III class) and area with SOC decrease (Figure 9). 


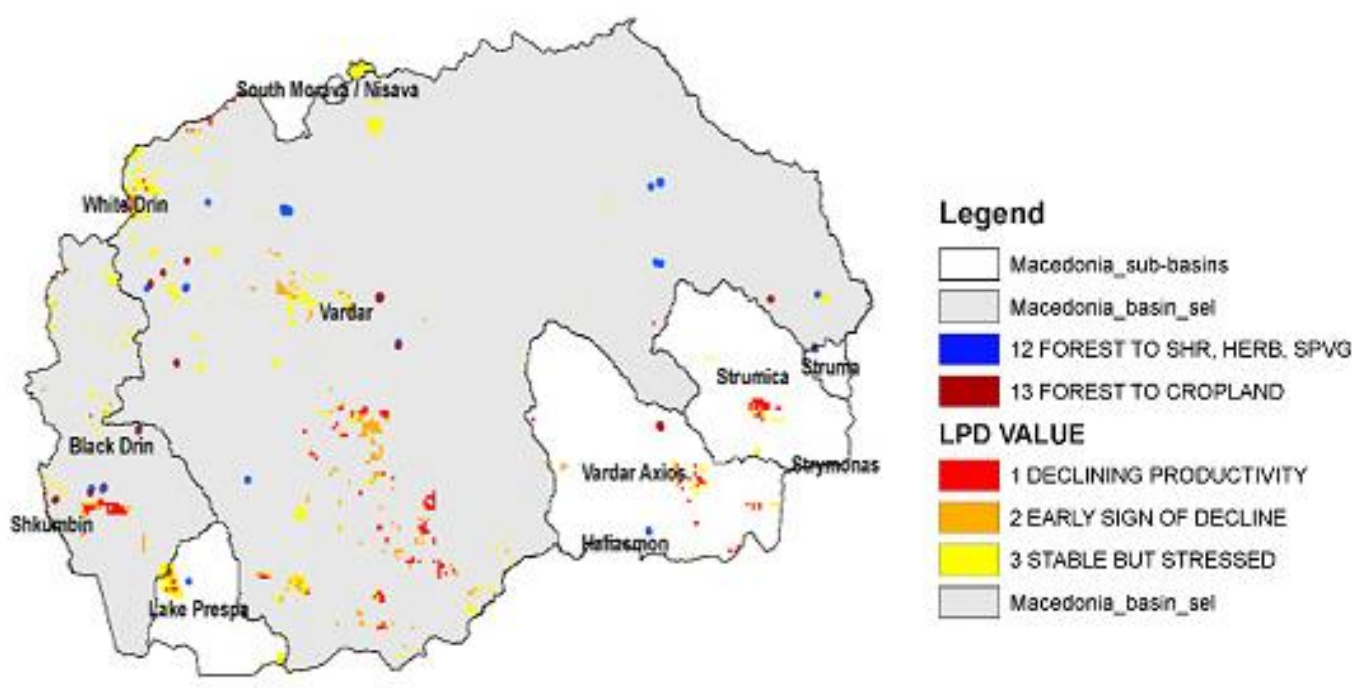

Figure 9. Cumulative Land degradation per watershed and priority watersheds

According to the ESA CCI data, the total degraded area is $588.6 \mathrm{sq} . \mathrm{km}$ (LPD - $585 \mathrm{sq} . \mathrm{km}$ and SOC loss -2.6 sq. km). The area of degraded land per watershed according to the delineation by ESA CCI are presented in Table 7 (note: it is different than Macedonian delineation of watersheds). Total degraded area (negative status in dynamic of LPD +SOC) in the country cover $589 \mathrm{~km}^{2}$ out of which $585 \mathrm{~km}^{2}$ from LPD and $3.5 \mathrm{~km}^{2}$ with SOC losses. More detail data about cumulative land degradation per watersheds in the country is presented in the following table.

Table 7. Cumulative land degradation per watersheds

\begin{tabular}{lccrcc}
\hline \multicolumn{1}{c}{ Watersheds } & Watershed area & LPD 1-3 area & SOC loss & $\begin{array}{c}\text { Degraded area } \\
\text { LPD+SOC }\end{array}$ \\
\hline & $\mathrm{km}^{2}$ & \multicolumn{1}{c}{$\mathrm{km}^{2}$} & $\mathrm{t}$ & $\mathrm{km}^{2}$ & $\mathrm{~km}^{2}$ \\
\hline Vardar & 20.331 .00 & 422.00 & -2.979 .00 & 2.00 & 424.00 \\
\hline Black Drim & 2.782 .00 & 124.00 & -855.00 & 0.00 & 124.00 \\
\hline Struma/Strumica & 1.699 .00 & 25.00 & -270.00 & 1.00 & 26.00 \\
\hline South Morava & 40.00 & 15.00 & 0.00 & 0.00 & 15.00 \\
\hline Total & 24.852 .00 & 586.00 & -4.104 .00 & 3.00 & 589.00 \\
\hline
\end{tabular}

\section{CONCLUSIONS}

Differences between two datasets for land cover/use changes: ESA_CCI and CORINE LC for the period 2000/2010 are significant.

Soil Organic Matter is estimated on the base of a global data and its dynamics over the period is limited to the land cover change.

Exhaustive and long term monitoring system of land degradation neutrality indicators dynamic should be established on a national level. Such system will enable implementing of Tier 2 and Tier 3 methodology for monitoring of LDN indicators.

The analyzes showed significant negative trend in dynamic of LDN indicators, due to what the country should adopt and implement "Land Degradation
Neutrality Target setting program" for achieving the obligations aroused from the SDG 15.3.

Acknowledgment. This study was a part of the project "UNCCD - Land degradation Neutrality Target Setting Program" - Country Report - Republic of Macedonia, financed by GEF - UNEP, 2018. Key national experts: prof. d-r Ivan Blinkov, prof. d-r Dusko Mukaetov.

\section{REFERENCES}

[1] L. Montanarella, D. J. Pennock, N. McKenzie, M. Badraoui, V. Chude, I. Baptista, T. Mamo, M. Yemefack, M. Singh Aulakh, K. Yagi, World's soils are under threat, Soil, 2 (2016), pp. 79-82.

[2] R. Lal, Climate Change and Soil Degradation Mitigation by Sustainable Management of Soils and 
Other Natural Resources, Agricultural Research, 1 (2012), pp. 199-212.

[3] H. J Geist, E. F. Lambin, Dynamic causal patterns of desertification, Bioscience, 54 (2004), pp. 817-829.

[4] J. Davies, M. Gudka, P. Laban, G. Metternicht, S. Alexander, I. Hannam, L. Welling, L. Vasseur, J. Siles, L. Aguilar, L. Poulsen, M. Jones, L. Nakanuku-Diggs, J. Zeidler, H. Frits, Land Degradation Neutrality: implications and opportunities for conservation Nature Based Solutions to Desertification, Land Degradation and Drought. Second Edition 27/08/2015.

[5] UNCCD - United Nation Convention to Combat Desertification, Land Degradation Neutrality Target Setting - A Technical Guide (2016), https://knowledge.unccd.int/publication/ldn-targetsetting-technical-guide

[6] UN-Habitat-GLTN, Scoping and Status Study on Land and Conflict: Towards UN System-Wide Engagement at Scale, (2016).

[7] E. Aynekulu, M. Lohbeck, R. Nijbroek, J. C. Ordoñez, K. G. Turner, T. Vågen, and L. Winowiecki, Review of methodologies for land degradation neutrality baselines: Sub-national case studies from Costa Rica and Namibia. Nairobi, Kenya, (2017).

[8] UNCCD - United Nation Convention to Combat Desertification, Methodological note to set national voluntary Land Degradation Neutrality (LDN) targets using the UNCCD indicator framework (2017), https://knowledge.unccd.int/sites/default/files/201808/LDN\%20Methodological\%20Note_02-06-2017 $\% 20$ ENG.pdf

[9] L. A. Cowie, J. B. Orr, M. V. Castillo, P. Chasek, D.N.Crossman, A.Erlewein, G. Louwagie, M. Maron, I. G. Metternicht, S. Minelli, E. A. Tengberg, S. Walter, S. Welton, Land in balance: The scientific conceptual framework for Land Degradation Neutrality, Environmental Science and Policy, 79 (2018), pp. 25-35.

[10] UNCCD - United Nation Convention to Combat Desertification, The LDN target setting programme, https://www.unccd.int/actions/ldn-targetsetting-programme

[11] A. J. Conacher, M. Sala, Land Degradation in Mediterranean Environments of the World: Nature and Extent, Causes and Solutions, edited by A. J. Conacher and M. Sala. Wiley, Chichester, 1998. ISBN 0471963178

[12] S. Bajocco, A. De Angelis, L. Perini, A. Ferrara, L. Salvati, The Impact of Land Use/Land Cover Changes on Land Degradation Dynamics: A Mediterranean Case Study, Environ. Manag., 49 (2012), pp. 980-989.

[13] M. Cherlet, E. Ivits, S. Sommer, G. Toyh, A. Jones, L. Montanaraella, A. Belward, Land-productivity dynamics in Europe, Towards valuation of land degradation in the EU, JRC Scientific and policy Reports (2013) (p. 61).

[14] J. G. Conijn, G. Z. Bai, S. P. Binbrapan, B. Rugtges, Global changes of net primary productivity affected by climate and abrupt land use changes in 1981 - Towards mapping of global degradation, - ISRIC Report (2013).

[15] H. Demirel, C. Ozcinar, G. Anbarjafari, Satellite image contrast enhancement using discrete wavelet transform and singular value decomposition. IEEE Geosciences and remote sensing letters, 7 (2010), pp. 333-337.

[16] M. C. Edwards, J. Wellens, D. Al-Eısaw1, Monitoring the grazing resources of the Badia region, Jordan, using remote sensing, Applied Geography, 19 (1999), pp. 385-398.

[17] Y. Ban, P. Gong, C. Giri, Global land cover mapping using Earth observation satellite data: Recent progresses and challenges, ISPRS Journal of Photogrammetry and Remote Sensing, 103 (2015), pp. $1-6$.

[18] O. Dengiz, Potential impact of land use change on land productivity dynamics with focus on land degradation in a sub-humid terrestrial ecosystem, Theoretical and Applied Climatology, 133, Issue 12 (2017), pp 73-88.

[19] R. Amundson, The Carbon Budget in Soils, Annual Review of Earth and Planetary Sciences, 29 (2001), pp. 535-562.

[20] Li-xia Yang, Pan Jian-jun, Dynamics models of soil organic carbon, Journal of Forestry Research,14, Issue 4 (2003), pp 323-330.

[21] IPCC, 2006 Guidelines for National Greenhouse Gas Inventories, Volume 4 - Agriculture, forestry and other land use, https://www.ipcc-nggip.iges.or.jp/public/2006gl/

\section{Global GIS/|RS Data Set received by UNCCD office}

[1] ESA Climate Change Initiative Land Cover dataset: spatial resolution 300m; 3 epochs 2000, 2005 and 2010 (2015 available shortly)

[2] JRC Land Productivity Dynamics dataset: 15-year time series (1999 to 2013) of SPOT Vegetation NDVI: spatial resolution $1 \mathrm{~km}$.

[3] ISRIC SoilGrids250m (2016, in prep.)

[4] LDN related tabular database

\section{Other Global Data set}

[1] EU - CORINE Land Cover/Use dataset (2000, 2006, 2012) https://land.copernicus.eu/pan-european/corine-land-cover 


\title{
ДИНАМИКА НА ИНДИКАТОРИТЕ ЗА ОЦЕНКА НА СТАТУСОТ НА НЕУТРАЛНОСТА НА ДЕГРАДАЦИЈАТА НА ЗЕМЈИШТЕТО ВО РЕПУБЛИКА МАКЕДОНИЈА
}

\author{
Душко Мукаетов ${ }^{1}$, Иван Блинков ${ }^{2,3}$, Христина Попоска $^{1}$ \\ 1Земјоделски институт, Универзитет „Св. Кирил и Методиј“, Скопје, Република Македонија \\ ${ }^{2}$ Шумарски факултет, Универзитет „Св. Кирил и Методиј“, Скопје, Република Македонија \\ ${ }^{3}$ Истражувачки центар за животна средина и материјали, \\ Македонска академија на науките и уметностите, Скопје, Република Македонија
}

\begin{abstract}
Неутралноста на деградацијата на земјиштето (НДЗ) е дефинирано како состојба при која количината и квалитетот на земјишните ресурси потребни за поддршка на екосистемските функции и услуги, како и подобрувањето на безбедноста на храната остануваат стабилни или се зголемуваат во рамките на одредени временски и просторни рамки и екосистеми. Основната состојба (baseline) е изразена како почетна (t0) проценета вредност на секоја од трите индикатори што се користат како референтни за процена на природниот капитал заснован врз земјишните ресурси, како и екосистемските услуги што произлегуваат од него, и тоа: земјишната покривка/промена во земјишата покривка, статусот и трендовите во однос на продуктивноста на земјиштето, како и статусот и трендовите во однос на содржината на органски јаглерод во почвата.

Основната линија на НДЗ е пресметана со процена на просечните вредности во текот на референтен период од 10 години за следниве индикатори: земјишна покривка/промена на земјишната покривка (LC/LCC), динамика на продуктивноста на земјиштето (LPD) и почвениот органски јаглерод (SOC). Беа користени три нивоа (Tier) за пресметување на избраните индикатори: Tier 1 ниво: користење глобално/регионално набљудување на Земјата, геопросторни информации и моделирање; Tier 2 ниво: користење национална статистика (само за LC/LCC) и Tier 3 ниво: теренско испитување. Најзначајни промени во однос на земјишната покривка за периодот 2000 - 2012 година се во категориите шуми и грмушки/пасишта. Според глобалните бази на податоци, што беа користени за анализа на продуктивноста на земјиштето, вкупната погодена област со намалување на продуктивноста на земјиштето за периодот 2000 - 2010 година е идентификувана на само $2.35 \%$ од територијата на земјата. Достапната глобална бази на податоци содржи податоци добиени по пат на моделирање за содржината на почвен органски јаглерод (SOC) за периодот 2000 - 2010 година. Според овие податоци, вкупната загуба на СПЦ во нашата земја се проценува на $3951 \mathrm{t}$.
\end{abstract}

Клучни зборови: неутралност на деградација на земјиштето; промена на покровноста/искористувањето на земјиштето; продуктивност на земјиштето; почвена органска материја 
